\title{
Malignant hyperthermia as a rare cause of SIRS after cardiac surgery
}

\author{
Nils Theuerkauf*, Fritz Mellert, Ulf Guenther \\ From 33rd Annual Meeting of the European Malignant Hyperthermia Group (EMHG) \\ Würzburg, Germany. 15-17 May 2014
}

\section{Background}

Use of extracorporal circulation (cardiopulmonary bypass) during cardiac surgery can cause a systemic inflammatory response. This so called "post-perfusionsyndrome" (PPS) occurs in about a quarter of patients and results in clinical signs and symptoms of "systemic inflammatory response syndrome" (SIRS) in $2-10 \%$ of patients. This condition is clinically associated with mild hyperthermia, acidosis, tachycardia and vasoplegia. It is generally treated with cristalloid infusions and vasopressors, and is mostly subsided by the next morning, at the latest after $48 \mathrm{~h}$.

Malignant hyperthermia is associated with a severe combined (respiratory and metabolic) acidosis, hyperlactatemia, hypercapnia, hyperthermia, grossly elevated serum levels of creatine kinase (CK) and acute renal failure.

\section{Case report}

We present a 23-year old patient, who gradually developed multi-organ failure following mitral valve repair for severe secondary mitral regurgitation due to dilated cardiomyopathy. His past medical history included partial hepatectomy for hepatoblastoma in childhood (1982) and partial lung resection due to recurrent pneumothoraces in 2002. Induction of general anesthesia was carried out with thiopentone, sufentanil and cis-atracurium and was maintained with isoflurane as the hypnotic agent. Following surgery, the patient showed increased infusion requirements and was highly vasopressor-dependent. Due to oliguric renal failure and refractory metabolic acidosis, continuous veno-venous hemodiafiltration was instituted early. Increased volume and vasopressor needs gradually decreased within the first 30 hours. In conjunction with two episodes of body temperature

Department of Anesthesia and Critical Care, University Hospital of Bonn, Bonn, 53127, Germany 
taken into account, even if the clinical course is rather mild in a way so that $\mathrm{MH}$ appears almost unlikely.

Published: 18 August 2014

doi:10.1186/1471-2253-14-S1-A10

Cite this article as: Theuerkauf et al: Malignant hyperthermia as a rare cause of SIRS after cardiac surgery. BMC Anesthesiology 2014 14(Suppl 1): A10.

Submit your next manuscript to BioMed Central and take full advantage of:

- Convenient online submission

- Thorough peer review

- No space constraints or color figure charges

- Immediate publication on acceptance

- Inclusion in PubMed, CAS, Scopus and Google Scholar

- Research which is freely available for redistribution 